\title{
CZYNNIKI WYTWÓRCZE W BRANŻY PRZETWÓRSTWA RYBNEGO W POLSCE W OKRESIE POAKCESYJNYM
}

\author{
Sebastian Kubala \\ Katedra Rozwoju Organizacji, Uniwersytet Ekonomiczny w Krakowie \\ Kierownik Katedry: prof. zw. dr hab. Krzysztof Firlej
}

\begin{abstract}
Słowa kluczowe: czynniki produkcji, produktywność cząstkowa, produktywność całkowita, funkcja produkcji Cobba-Douglasa, gospodarka rybna

Key words: factors of production, partial productivity, total productivity, Cobb-Douglas production function, fish economy

JELcode: D23, O4, O13, Q22
\end{abstract}

S y n o p s i s. Badanie poziomu oraz tempa zmian poziomu produktywności poszczególnych sektorów umożliwia ocenę efektywności wykorzystywanych zasobów oraz identyfikację źródeł wzrostu produkcji. Obrazuje, w jakim stopniu poziom zmian w danej branży zależy od czynników pracy oraz kapitału. Celem opracowania jest określenie efektywności wykorzystania czynników produkcji w branży przetwórstwa rybnego w Polsce w latach 2005-2016. Do ustalenia tempa zmian efektywności czynników wytwórczych wykorzystano wskaźniki oparte na produkcji, zatrudnieniu oraz wartości brutto środków trwałych. Zaprezentowane badania wykazały, iż w branży przetwórstwa rybnego występowała generalna tendencja wzrostu produktywności pracy. Jednocześnie można było zaobserwować niekorzystne zmiany produktywności kapitału. Przeprowadzone badania wskazują, iż większy wpływ na poziom produkcji ma czynnik kapitału aniżeli poziom zatrudnienia. Ponadto wartość produkcji wzrastała $\mathrm{w}$ tempie szybszym niż łączne nakłady czynników ją kształtujących.

\section{WSTĘP}

Produktywność zalicza się do jednej z podstawowych kategorii nauk ekonomicznych. Stanowi ona obraz efektywności ponoszonych nakładów i jest jednym z kluczowych elementów decydujących o rozwoju sektorów gospodarki narodowej. Globalizacja powoduje wzrost poziomu konkurencyjności na rynkach, co wywołuje konieczność stosowania coraz bardziej efektywnych sposobów gospodarowania oraz wymusza zwiększenie stopnia racjonalizacji wykorzystania czynników wytwórczych. Produktywność obejmuje podstawowe relacje, które zachodzą pomiędzy poziomem produkcji a czynnikami, które są zaangażowane $\mathrm{w}$ działalność przedsiębiorstwa. Powoduje to, że jest ona uznawana za jeden z podstawowych wskaźników potencjału konkurencyjnego. Wzrost poziomu produktywności czynników wytwórczych jest podstawą właściwego rozwoju jednostki gospodarczej, który kształtuje obecną oraz przyszłą wartość przedsiębiorstwa. Jej wyższy poziom oznacza zwiększony poziom efektywności, który jednocześnie jest czynnikiem stanowiącym o przewadze konkurencyjnej. 
Jednym z narzędzi do określania poziomu produktywności jest funkcja produkcji, która ściśle przedstawia określoną relację między poziomem produkcji a jej podstawowymi czynnikami: pracą ludzką oraz kapitałem. W ostatnich latach nastąpiła ewolucja obszarów badawczych produktywności, głównie w kierunku badania wydajności poszczególnych czynników produkcji (produktywności cząstkowej) oraz badania łącznej wydajności wszystkich rodzajów nakładów (produktywności całkowitej). Badania w sektorze spożywczym zostały przedstawione w: [Adamczyk 2008, Adamczyk 2009, Gołaś 2010, Latruffe 2010, Juchniewicz, Urban 2012, Szczepaniak 2012, Mroczek, Tereszczuk 2013 i inni].

Badanie poziomu oraz tempa zmian poziomu produktywności poszczególnych sektorów jest szczególnie istotne. Umożliwia nie tylko ocenę efektywności wykorzystywanych zasobów, a więc czynników pracy oraz kapitału, ale również identyfikację źródeł wzrostu produkcji. Obrazuje zależność zmian w danej branży od czynników pracy oraz kapitału.

Przystąpienie Polski do Unii Europejskiej (UE) stało się czynnikiem powodującym istotne zmiany w sektorze spożywczym. Stanowiło ono bodziec do stopniowego rozwoju rolnictwa oraz do wzrostu poziomu konkurencyjności całej gospodarki żywnościowej [Firlej 2017]. Szczególne ożywienie inwestycyjne nastąpiło po akcesji Polski do Unii Europejskiej dzięki aktywnie prowadzonej polityce pozyskiwania kredytów oraz funduszy pomocowych. Głęboki stopień restrukturyzacji oraz zmiany jakościowe produktów spowodowały, że w ostatnich latach grupa produktowa przetworów rybnych znacznie się rozwinęła, głównie poprzez wzrost spożycia ryb przez społeczeństwo czy też wzrost popytu krajowego [Firlej, Kubala 2017]. Wprowadzenie rygorystycznych standardów w procesie przetwarzania produktów rybnych, liczne wymogi oraz certyfikaty stanowią czynniki, $\mathrm{z}$ którymi muszą radzić sobie firmy funkcjonujące $\mathrm{w}$ branży rybnej. $Z$ drugiej strony, jak wskazali Sebastian Kubala i Krzysztof Firlej, Polska jest państwem o niskim stopniu efektywności branży przetwórstwa rybnego (przekształcania nakładów w efekty), mimo że ma w regionie państw nadbałtyckich jeden z największych udziałów w wielkości połowów ryb oraz produkcji z akwakultury. Główną przyczyną tego zjawiska jest niska rentowność wykorzystywanych zasobów ludzkich w branży rybnej [Kubala, Firlej 2018].

Celem opracowania jest określenie efektywności wykorzystania czynników produkcji w branży przetwórstwa rybnego w Polsce w latach 2005-2016. Do określenia tempa zmian efektywności czynników wytwórczych wykorzystano wskaźniki oparte na produkcji, zatrudnieniu oraz wartości brutto środków trwałych. Przedstawiono również zależność produkcji omawianego sektora od zasobów pracy i kapitału za pomocą funkcji produkcji Cobba-Douglasa.

\section{MATERIAŁ I METODYKA BADAŃ}

Do pomiaru produktywności zastosowano wskaźniki produktywności cząstkowej oraz całkowitej. Pierwsza grupa wskaźników ma na celu prezentację efektywności poszczególnych nakładów, które są wykorzystywane do produkcji. Stanowią one relację całkowitej produkcji do wielkości poszczególnych czynników produkcji, którymi są nakłady pracy oraz nakłady kapitału. W pracy posłużono się następującymi wzorami:

$\mathrm{Q} / \mathrm{L}$ 
$\mathrm{Q} / \mathrm{K}$

gdzie: Q - wielkość produkcji, $\mathrm{K}$ - nakład kapitału, L - nakład pracy.

Produktywność całkowita została oszacowana na podstawie neoklasycznej funkcji produkcji Cobba-Douglasa [Cobb, Douglas 1928]:

$$
\mathrm{Q}=\mathrm{A}_{0} \mathrm{~K}^{\alpha_{1}} \mathrm{~L}^{\alpha_{2}}
$$

gdzie: $\mathrm{Q}$ - wielkość produkcji, $\mathrm{K}$ - nakład kapitału, $\mathrm{L}$ - nakład pracy, $\mathrm{A}_{0}>0$ - łączna produktywność w roku $\mathrm{t}=0$ (wyraz wolny) $, \alpha_{1}, \alpha_{2}$ - parametry strukturalne modelu.

Parametry strukturalne funkcji Cobba-Douglasa informują o elastyczności produkcji względem nakładów. Suma tych parametrów $\left(v=\alpha_{1}+\alpha_{2}\right)$ wskazuje na efekty skali. Informuje, czy produkcja wzrastała $\mathrm{w}$ tym samym tempie $(\mathrm{v}=1)$, wolniej $(\mathrm{v}<1)$, czy szybciej $(v>1)$ niż czynniki produkcji. Ocenę przydatności oszacowanej funkcji przeprowadzono na podstawie analizy współczynnika determinacji $\left(\mathrm{R}^{2}\right)$, błędu standardowego estymacji oraz istotności statystycznej zmiennych funkcji. Do oceny istotności zestawu parametrów strukturalnych zastosowano test $\mathrm{F}$ [Borkowski i in. 2003].

Zgodnie z podejściem tradycyjnym, za wielkość produkcji (Q) przyjęto przychody ze sprzedaży, za czynnik ludzki (L) przyjęto wielkość zatrudnienia, za czynnik kapitału (K) zaś - wartość brutto środków trwałych [Holtz-Eakin 1994, Nadiri, Nandi 1999].

Do przeprowadzenia badań wykorzystano dane statystyczne za lata 2005-2016 opublikowane przez Główny Urząd Statystyczny dotyczące podmiotów gospodarczych funkcjonujących w branży przetwórstwa rybnego. Do branży przetwórstwa rybnego zgodnie z klasyfikacją PKD zaliczono: przetwarzanie i konserwowanie ryb, skorupiaków i mięczaków (10.20) oraz wytwarzanie gotowych posiłków i dań (10.85). Zmienne przedstawione w ujęciu pieniężnym zostały sprowadzone do cen stałych z 2005 r. przy wykorzystaniu wskaźnika cen towarów i usług konsumpcyjnych.

\section{CHARAKTERYSTYKA BRANŻY PRZETWÓRSTWA RYBNEGO W POLSCE}

Przetwórstwo ryb należy do jednej z najszybciej rozwijających się branż przemysłu spożywczego w Polsce. Czynniki wpływające na wzrost konkurencyjności zakładów przetwórczych tej branży w badanym okresie były zróżnicowanie. Był to wynik przeprowadzenia głębokich zmian restrukturyzacyjnych, gdyż w okresie przedakcesyjnym konieczne stało się dostosowanie istniejących zakładów do wysokich wymagań higieniczno-weterynaryjnych [Koszarek 2005]. Szczególnie ważne okazało się wsparcie z funduszy SAPARD i SPO „Rybołówstwo i przetwórstwo ryb 2004-2006”, a także prawidłowa absorbcja środków z Programu Operacyjnego „Zrównoważony rozwój sektora rybołówstwa i nadbrzeżnych obszarów rybackich 2007-2013”.

Według Pawła Czaplińskiego, czynnikami, które przesądzają o wysokim poziomie konkurencyjności polskiego przetwórstwa rybnego w Unii Europejskiej, są: duży stopień zaawansowania technologicznego, wysoka sprawność techniczna w połączeniu z bardzo dobrą jakością produktów oraz relatywnie niskie koszty pracy [Czapliński 2011]. 
Istotnym czynnikiem wpływającym na rozwój polskiego przetwórstwa ryb był również rosnący deficyt surowca zgłaszany przez wiele krajów Unii Europejskiej. Podobne wnioski wskazał Krzysztof Hryszko, który uznał handel zagraniczny wyrobami rybnymi za jeden z głównych czynników w zasadniczym stopniu determinujących możliwości funkcjonowania sektora [Hryszko 2014], co szczegółowo prezentuje tabela 1. Wskazał on, że w okresie przedakcesyjnym import $\mathrm{w}$ głównej mierze był wynikiem rosnącego popytu na wiele do tej pory nieznanych na rynku polskim gatunków ryb, z kolei po integracji zaobserwowano wzrost eksportu polskich produktów. Głównymi rynkami zbytu polskich wyrobów rybnych były w latach 2005-2008: Niemcy, Dania, Wielka Brytania oraz Francja [Morska ... 2006-2009]. Po wstąpieniu Polski do Unii Europejskiej największe korzyści odniosły firmy, które importowały produkty rybne z obecnych państw członkowskich Unii Europejskiej, największe straty zaś poniosły państwa EFTA, w których przypadku wejście Polski w struktury UE oznaczały koniec obowiązywania umów o wolnym handlu [Hryszko i in. 2014].

Tabela 1. Wybrane informacje dotyczące handlu zagranicznego rybami, mięczakami

i skorupiakami i ich przetworami, spożycia ryb oraz liczby zatrudnionych i wartości brutto środków trwałych w branży przetwórstwa rybnego w Polsce w latach 2005-2016

\begin{tabular}{cccccc}
\hline Lata & $\begin{array}{c}\text { Eksport } \\
\text { w tys. ton }\end{array}$ & $\begin{array}{c}\text { Import } \\
\text { w tys. ton }\end{array}$ & $\begin{array}{c}\text { Spożycie ryb } \\
\text { w kg na mieszkańca }\end{array}$ & $\begin{array}{c}\text { Liczba } \\
\text { zatrudnionych }\end{array}$ & $\begin{array}{c}\text { Wartość brutto środków } \\
\text { trwałych w mln zł } \\
\text { (ceny stałe z 2005 roku) }\end{array}$ \\
\hline 2005 & 207,1 & 321,5 & 11,73 & 14538 & 880,3 \\
2006 & 220,9 & 352,0 & 12,33 & 16439 & 1160,8 \\
2007 & 243,4 & 377,2 & 13,86 & 17237 & 1381,7 \\
2008 & 252,0 & 425,0 & 14,72 & 17595 & 1751,6 \\
2009 & 328,8 & 419,8 & 13,15 & 18180 & 2069,1 \\
2010 & 325,9 & 465,9 & 13,00 & 18844 & 2402,5 \\
2011 & 351,5 & 450,9 & 12,27 & 17711 & 2647,5 \\
2012 & 364,7 & 465,5 & 11,70 & 18224 & 2964,4 \\
2013 & 407,4 & 504,9 & 12,17 & 19549 & 2981,7 \\
2014 & 366,4 & 519,7 & 13,45 & 20208 & 3367,8 \\
2015 & 409,8 & 530,7 & 12,47 & 20136 & 3534,1 \\
2016 & 423,2 & 559,1 & 13,11 & 21055 & 4129,5 \\
\hline
\end{tabular}

Źródło: opracowanie własne na podstawie danych IERiGŻ.

Na znaczenie uwarunkowań społecznych wskazał Piotr Bykowski, który za jeden z najważniejszych czynników wpływających na rozwój polskiego przetwórstwa rybnego uznał szybko zachodzące zmiany demograficzne [Bykowski 2010]. Jego zdaniem społeczeństwo wykazuje duży popyt na żywność wysoko przetworzoną i interesuje się potrawami regionalnymi z całego świata.

Strukturę sektora przetwórstwa rybnego w Polsce należy uznać za bardzo rozdrobnioną. Większość podmiotów (około 80\%) należy do przedsiębiorstw małych oraz średnich. Większym poziomem konkurencyjności charakteryzują się duże jednostki, które mają znaczną część udziału dochodów tego rynku i to właśnie przez te jednostki kształtowany jest rozwój branży [Firlej, Kubala 2017]. Zgodnie z rejestrem Głównego Inspektoratu Weterynarii (GIW) na koniec 2016 roku w Polsce funkcjonowało 262 zakładów prze- 
twórczych, które były uprawnione do handlu produktami rybnymi na obszarze Unii Europejskiej [Rynek ryb... 2017]. W porównaniu do roku 2005 ich liczba zwiększyła się o 72 zakłady. Wśród jednostek działających w branży przetwórstwa rybnego charakterystyczną cechą jest ich aktywna działalność w przejmowaniu firm i budowaniu skonsolidowanej grupy producenckiej. Największa liczba zakładów znajduje się w regionie nadmorskim (rys. 1.). W województwach pomorskim i zachodniopomorskim w 2005 roku $\mathrm{z}$ uprawnieniami handlu z krajami Unii Europejskiej funkcjonowało 59,5\% wszystkich przetwórni w kraju, zaś w 2016 roku 53,1\%. Na pozostałym obszarze kraju najwięcej zakładów tego rodzaju znajdowało się w województwach: warmińsko-mazurskim, wielkopolskim, śląskim i mazowieckim. W odniesieniu do zakładów, których produkty dopuszczono do sprzedaży bezpośredniej na rynkach lokalnych, to ich liczba pomiędzy latami 2005 i 2016 zwiększyła się o około 20 jednostek przetwórczych. W 2016 roku ich liczba była szacowana na 60-70 zakładów. Są to jednak dane szacunkowe, bowiem niewielka grupa zakładów, których produkty dopuszczono do sprzedaży bezpośredniej na rynkach lokalnych, zajmuje się przetwórstwem ryb (ogólna liczba takich zakładów w 2016 roku wyniosła 885 podmiotów).

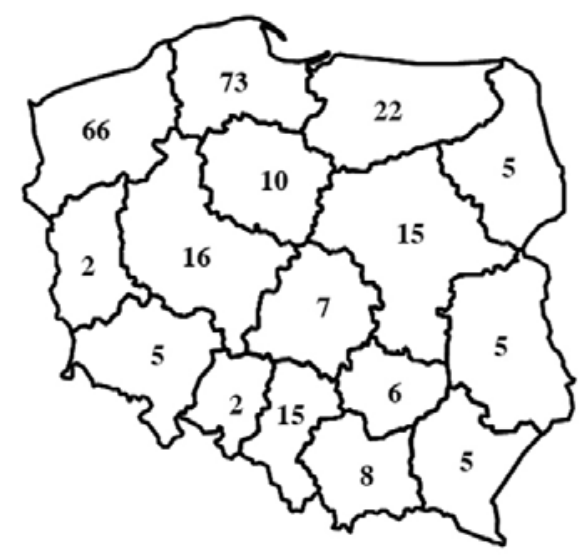

Rysunek 1. Rozmieszczenie zakładów przetwórstwa rybnego z uprawnieniami do handlu na rynku UE (stan na koniec 2016 r.)

Źródło: opracowanie własne na podstawie danych GIW.

Analizując poziom spożycia ryb w latach 2005-2016 w Polsce, zaobserwowano zróżnicowane trendy (tabela 1.). W latach 2005-2008 następował stopniowy wzrost spożycia ryb z poziomu $11,73 \mathrm{~kg}$ na 1 mieszkańca do poziomu $14,72 \mathrm{~kg}$ na 1 mieszkańca. W następnych latach trend odwrócił się i utrzymał się do roku 2012 (stopniowy spadek spożycia ryb do poziomu $11,7 \mathrm{~kg}$ na 1 mieszkańca). Kolejne lata to wahania stopnia spożycia ryb. Bazując na danych budżetów gospodarstw domowych, trzeba zauważyć, że w 2016 roku spożycie ryb zwiększyło się o 5,13\% w stosunku do roku poprzedniego i wyniosło $13,11 \mathrm{~kg}$ na 1 mieszkańca. Do głównych czynników decydujących o poziomie spożycia ryb zaliczyć należy ich ceny oraz stopień jakości wyrobów. Coraz częściej trendy spożycia wywołane są wzrostem świadomości konsumentów na temat zdrowego odżywiania. 


\section{CZYNNIKI WYTWÓRCZE I PRZYCHODY ZE SPRZEDAŻY W BRANŻY PRZETWÓRSTWA RYBNEGO W POLSCE - WYNIKI BADAŃ}

W latach 2005-2016 liczba osób zatrudnionych w przetwórstwie rybnym (tabela 1. i rys. 2.) wykazywała tendencję rosnącą, oprócz lat 2011 oraz 2015, kiedy nastąpił jej spadek. Pomiędzy latami 2014 i 2015 zatrudnienie spadło zaledwie 0,36\%, natomiast pomiędzy latami 2010 i 2011 redukcja była znaczna (spadek o 6,01\%), czego głównym powodem był trudny okres dla branży spowodowany wzrostem cen surowców rybnych. W roku 2016 w przetwórstwie rybnym zatrudnianych było o 44,83\% więcej pracowników niż w roku 2005. Szczególnie wysoki poziom wzrostu zatrudnienia zanotowano w okresie poakcesyjnym (rok 2006), w którym w stosunku do roku poprzedniego odnotowano wzrost zatrudnienia o 13,08\%. Ogólnym problemem dotyczącym kwestii zatrudnienia w branży przetwórstwa rybnego jest brak pracowników zarówno mniej wykwalifikowanych, jak i pracowników o wyższym poziomie wykształcenia. W przetwórstwie rybnym istnieje deficyt pracowników, który znacząco wpływa na poziom jakości produkcji, a w konsekwencji na poziom ich zysków [Morska... 2017].

Wartość brutto środków trwałych w latach 2005-2016 stopniowo wzrastała, z wyjątkiem roku 2013, w którym nastąpił spadek ich wartości (tabela 1. i rys. 3.). Pomiędzy latami 2005 i 2016 wartość brutto środków trwałych wzrosła o 369,10\%. Największy przyrost majątku trwałego odnotowano pomiędzy latami 2005 i 2006, gdy odnotowano wzrost ich wartości o $31,86 \%$.

Poziom osiąganych przychodów ze sprzedaży w latach 2005-2016 stopniowo wzrastał (tabela 2. i rys. 4.). Wzrost pomiędzy tymi latami nastąpił o 332,81\% (w ujęciu wartościowym o $11027,6 \mathrm{mln}$ zł). Przyczyną tendencji wzrostowej było racjonalne wykorzystanie środków Unii Europejskiej przyznawanych na modernizację zakładów produkcyjnych umożliwiających wzrost ich zdolności produkcyjnych. Najszybszy przyrost osiąganych przychodów ze sprzedaży odnotowano pomiędzy latami 2005 i 2006, gdy odnotowano wzrost ich poziomu o $32,86 \%$. Był to skutek zwiększenia skali produkcji z jednoczesnym

Tabela 2. Przychody ze sprzedaży, produktywność pracy i kapitału w branży przetwórstwa rybnego w Polsce w latach 2005-2016

\begin{tabular}{cccc}
\hline Lata & $\begin{array}{c}\text { Przychody ze sprzedaży w mln zł } \\
\text { (ceny stałe z 2005 roku) }\end{array}$ & $\begin{array}{c}\text { Produktywność pracy } \\
\text { w tys. zł na osobę }\end{array}$ & $\begin{array}{c}\text { Produktywność kapitału } \\
\text { [zł/zł] }\end{array}$ \\
\hline 2005 & 3216,8 & 221,3 & 3,65 \\
2006 & 4255,3 & 258,9 & 3,67 \\
2007 & 4775,1 & 277,0 & 3,46 \\
2008 & 5419,4 & 308,0 & 3,09 \\
2009 & 6811,8 & 374,7 & 3,29 \\
2010 & 7358,4 & 390,5 & 3,06 \\
2011 & 8312,5 & 469,3 & 3,14 \\
2012 & 9272,4 & 508,8 & 3,13 \\
2013 & 10674,9 & 546,1 & 3,58 \\
2014 & 11415,7 & 564,9 & 3,39 \\
2015 & 12103,5 & 601,1 & 3,42 \\
2016 & 14244,4 & 676,5 & 3,45 \\
\hline
\end{tabular}

Źródło: opracowanie własne na podstawie danych GUS. 


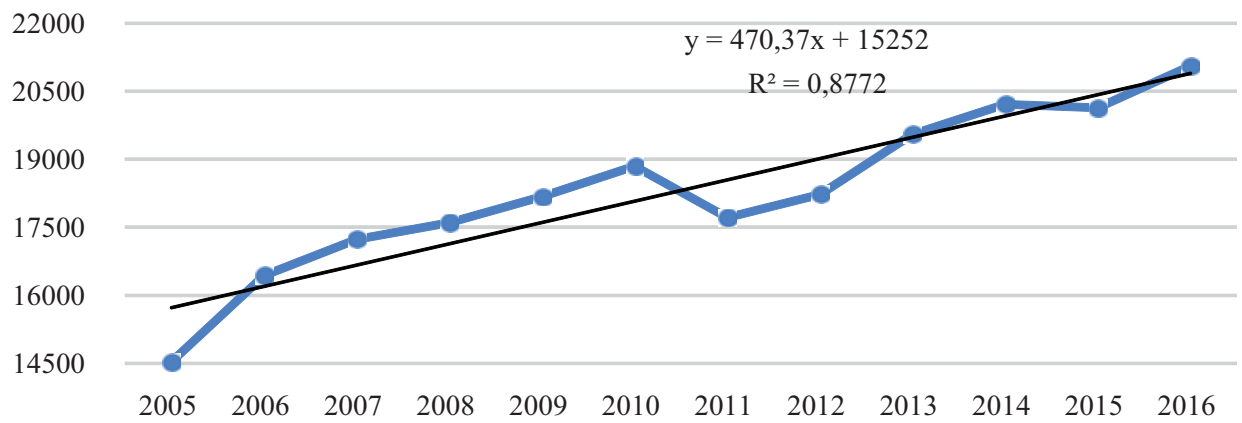

Rysunek 2. Liczba osób zatrudnionych w branży przetwórstwa rybnego w Polsce w latach 20052016 (stan zatrudnienia na 31 grudnia)

Źródło: opracowanie własne na podstawie danych GUS.

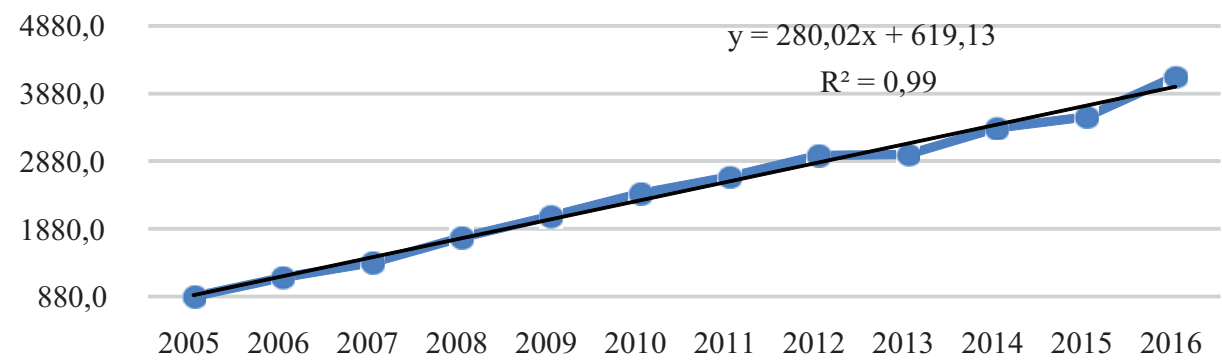

Rysunek 3. Wartość brutto środków trwałych w branży przetwórstwa rybnego w Polsce w latach 2005-2016 (w cenach stałych z 2005 roku, w mln zł)

Źródło: opracowanie własne na podstawie danych GUS.

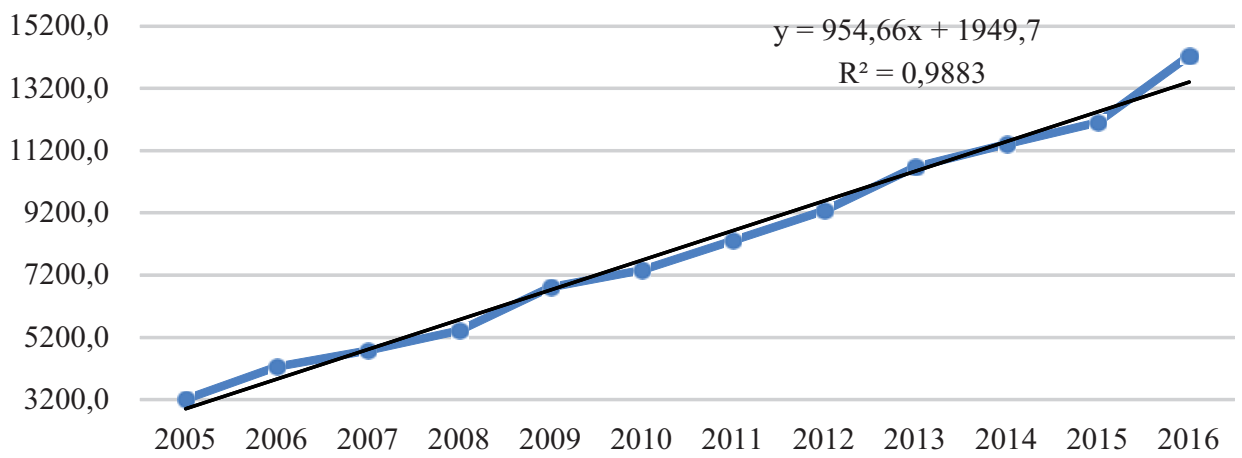

Rysunek 4. Przychody ze sprzedaży w branży przetwórstwa rybnego w Polsce w latach 2005-2016 (w cenach stałych z 2005 roku, w mln zl)

Źródło: opracowanie własne na podstawie danych GUS. 
zjawiskiem rosnących cen produktów rybnych. Warto zaznaczyć, że okres występowania najmocniejszych sygnałów kryzysu finansowo-gospodarczego nie wpłynął znacząco na osiągane wyniki przychodów ze sprzedaży. W 2016 roku największy udział w przychodach ze sprzedaży dotyczył sprzedaży ryb wędzonych (39\%), produktów głęboko zamrożonych (23\%) oraz produktów świeżych, niskoprzetworzonych (14\%).

\section{PRODUKTYWNOŚĆ CZYNNIKÓW WYTWÓRCZYCH W BRANŻY PRZETWÓRSTWA RYBNEGO W POLSCE - WYNIKI BADAŃ}

Jednym z podstawowych, a zarazem najważniejszych wskaźników produktywności jest wskaźnik produktywności pracy. Wyraża on wartość produkcji, która przypada na jednego zatrudnionego. W latach 2005-2016 poziom produktywności pracy stopniowo wzrastał, jednakże skala występujących zmian była różna (tabela 2.). Szczególnie wysoki przyrost poziomu produktywności pracy odnotowano w latach 2009 i 2011 (pomiędzy latami 2008 i 2009 poziom produktywności pracy wzrósł o 21,6\%, natomiast pomiędzy latami 2010 i 2011 o 20,2\%). W 2009 roku był to skutek szybszego tempa zmian osiąganych przychodów ze sprzedaży w stosunku do liczby osób zatrudnionych, natomiast w 2011 roku był to efekt dodatniego przyrostu przychodów ze sprzedaży $\mathrm{z}$ jednoczesnym zmniejszeniem liczby osób zatrudnionych w branży przetwórstwa rybnego. Jak wskazał Piotr Adamczyk wzrost produktywności pracy w tych latach w przemyśle spożywczym był konsekwencją lepszego wyposażenia siły roboczej w maszyny i urządzenia [Adamczyk 2008], co znajduje również odzwierciedlenie w branży przetwórstwa rybnego.

Kolejnym istotnym wskaźnikiem jest produktywność kapitału. Odzwierciedla ona wartość produkcji, która przypada na jednostkę zaangażowanego kapitału, a więc stanowi źródło oceny efektywności wykorzystania majątku przedsiębiorstw. W latach 2005-2016 poziom produktywności kapitału w branży przetwórstwa rybnego charakteryzował się znacznym stopniem zróżnicowania, w którym można było zaobserwować wahania wartości tego wskaźnika. Pomiędzy latami 2005 i 2016 zaobserwowano spadek poziomu produktywności kapitału o 5,48\%. Największy poziom produktywności kapitału odnotowano w roku 2006, w którym wartość wskaźnika kształtowała się na poziomie 3,67. Spadki produktywności kapitału w poszczególnych latach wywołane były większym tempem przyrostu wartości brutto środków trwałych w stosunku do tempa przyrostu przychodów ze sprzedaży. Uzupełnieniem powyższych miar jest przedstawienie produktywności całkowitej czynników wytwórczych. Tabela 3. obrazuje wyniki oszacowania parametrów modelu funkcji Cobba-Douglasa (3) w analizowanej branży przetwórstwa rybnego.

Obliczony model obrazuje badane zjawiska w stopniu dobrym, może więc stanowić podstawę prawidłowego wnioskowania o analizowanym procesie produkcyjnym. Wpływ na to ma wysoka wartość współczynnika determinacji $\mathrm{R}^{2}$ (oszacowany model wyjaśnia zmienność zmiennej objaśnianej w 98,4\%), niska wartość błędu standardowego estymacji $(0,064)$, a także wartość określająca wyniki testu F. Przeprowadzone testy istotności parametrów strukturalnych wykazały ich statystyczną istotność.

Oszacowane współczynniki wskazują, iż na osiągany poziom produkcji ma dodatni wpływ zarówno czynnik pracy, jak i czynnik kapitału. Jednakże większy wpływ na wartość produkcji w branży przetwórstwa rybnego miał czynnik kapitału reprezentowany 
Tabela 3. Wyniki estymacji modelu funkcji produkcji dla branży przetwórstwa rybnego

\begin{tabular}{|c|c|c|c|}
\hline Wyszczególnienie & $\mathrm{A}_{0}$ & $\alpha 1$ & $\alpha 2$ \\
\hline Współczynniki & 0,448 & 0,844 & 0,547 \\
\hline Współczynnik determinacji $\left(\mathrm{R}^{2}\right)$ & & 0,984 & \\
\hline Błąd standardowy modelu & & 0,064 & \\
\hline Statystyka F & & 284,5 & \\
\hline $\mathrm{p}$ & & $<0,00000$ & \\
\hline Funkcja produkcji Cobba-Douglasa & & $\mathrm{Q}=0,448 \mathrm{~K}^{0,844} \mathrm{~L}^{0,547}$ & \\
\hline
\end{tabular}

Źródło: opracowanie własne na podstawie danych GUS.

przez wartość brutto środków trwałych aniżeli poziom zatrudnienia. Współczynnik elastyczności produkcji względem kapitału wynosi 0,844 , względem pracy 0,547 . Zatem zwiększenie nakładu kapitału o $1 \%$ powoduje wzrost produkcji o $0,844 \%$, a zwiększenie nakładu pracy o $1 \%$ skutkuje wzrostem produkcji o $0,547 \%$ (przy założeniu niezmienności wielkości drugiego czynnika).

Suma współczynników elastyczności funkcji produkcji Cobba-Douglasa $\left(\mathrm{a}_{1}+\mathrm{a}_{2}\right)$ ma informować o wartościach tempa zmian pomiędzy wielkością produkcji a czynnikami ją kształtującymi. W branży przetwórstwa rybnego suma współczynników jest większa od jedności $\left(a_{1}+a_{2}>1\right)$, co wskazuje, iż wartość produkcji wzrastała w tempie szybszym niż łączne nakłady czynników ją kształtujących.

\section{PODSUMOWANIE}

Zaprezentowane badania miały na celu ukazanie efektywności wykorzystania czynników produkcji w branży przetwórstwa rybnego w Polsce w latach 2005-2016. Miały one również pomóc $\mathrm{w}$ określeniu zależności produkcji omawianego sektora od zasobów pracy i kapitału. Na ich podstawie sformułowano następujące wnioski:

1. Liczba osób zatrudnionych w branży przetwórstwa rybnego w latach 2005-2016 wykazywała, oprócz roku 2011 i 2015, tendencję wzrostową. W branży tej istnieje jednak problem z deficytem pracowników. Pozostałe dwa analizowane czynniki (osiągane przychody ze sprzedaży oraz wartość brutto środków trwałych) w latach 2005-2016 stopniowo wzrastały. Największy wzrost czynników wytwórczych odnotowano pomiędzy latami 2005 i 2006, co było wynikiem wdrażanych inwestycji w pierwszych latach członkostwa Polski w Unii Europejskiej, dzięki czemu polskie zakłady przetwórstwa rybnego podniosły poziom innowacyjności.

2. W branży przetwórstwa rybnego w analizowanym okresie występowała generalna tendencja wzrostu produktywności pracy. Jednocześnie można było zaobserwować niekorzystne zmiany produktywności kapitału, którego wskaźniki charakteryzowały się w latach 2005-2016 znacznymi wahaniami. Od momentu przystąpienia Polski do Unii Europejskiej do roku 2016 zaobserwowano spadek poziomu produktywności kapitału (o 5,48\%). Był to wynik większego tempa przyrostu wartości brutto środków trwałych w stosunku do przychodów ze sprzedaży. 
3. Czynniki wytwórcze branży przetwórstwa rybnego wykazały się dużym stopniem odporności na wahania koniunkturalne.

4. Przeprowadzone badania pozwalają stwierdzić, że większy wpływ na poziom produkcji ma czynnik kapitału aniżeli poziom zatrudnienia. Ponadto, wartość produkcji wzrastała w tempie szybszym niż łączne nakłady czynników ją kształtujących.

\section{LITERATURA}

Adamczyk Piotr 2008: Produktywność czynników wytwórczych w przemyśle spożywczym w Polsce, „Zeszyty Naukowe SGGW w Warszawie, Ekonomika i Organizacja Gospodarki Żywnościowej", $\mathrm{nr}$ 71, s. 95-106.

Adamczyk Piotr 2009: Substytucyjność czynników produkcji w przemyśle spożywczym w Polsce, „Zeszyty Naukowe SGGW w Warszawie, Ekonomika i Organizacja Gospodarki Żywnościowej”, nr 79, s. 111-123.

Borkowski Bolesław, Dudek Hanna, Szczesny Wiesław 2003: Ekonometria, Wybrane zagadnienia, Wydawnictwo Naukowe PWN, Warszawa.

Bykowski Piotr 2010, Przetwórstwo ryb w Polsce - szanse i zagrożenia, XXXV Krajowa Konferencja Hodowców Ryb Łososiowatych - materiały konferencyjne, Jastrzębia Góra, s. 53-62.

Cobb Charles, Douglas Paul 1928: A theory of production, „American Economic Review”, vol. 18 (1), s. 139-165.

Czapliński Paweł 2011: Funkcjonowanie przemystu przetwórstwa rybnego w Polsce $w$ okresie kryzysu gospodarczego, „Prace Komisji Geografii Przemysłu”, Warszawa-Kraków, s. 114$-128$.

Firlej Krzysztof 2017: Przemyst spożywczy w Polsce - nowa ścieżka rozwoju, Wydawnictwo Naukowe PWN, Warszawa.

Firlej Krzysztof, Kubala Sebastian 2017: Factors of Functioning and Chances of Development of Fish Industry in Poland, „Acta Scientiarum Polonorum, Oeconomica”, nr 16 (2), s. 33-43.

Gołaś Zbigniew 2010: Czynniki ksztattujace wydajność pracy w przedsiębiorstwach przemystu spożywczego, „Zagadnienia Ekonomiki Rolnej”, nr 4, s. 30-50.

Główny Urząd Statystyczny: Rocznik Statystyczny Gospodarki Morskiej 2006-2017.

Holtz-Eakin Douglas 1994: Public sector and the Productivity Puzzle, „The Review of Economics and Statistics", Harvard University, vol. 76/1, s. 12-21.

Hryszko Krzysztof 2014: Ceny transakcyjne w handlu zagranicznym a sytuacja ekonomiczno-finansowa sektora przetwórstwa ryb w Polsce, ,Roczniki Naukowe Stowarzyszenia Ekonomistów Rolnictwa i Agrobiznesu", nr XVI (2), s. 88-92.

Hryszko Krzysztof, Kuzebski Emil, Lirski Andrzej 2014, Sytuacja na światowym rynku ryb i jej wplyw na rozwój sektora rybnego $w$ Polsce, IERiGŻ-PIB, Warszawa.

Juchniewicz Małgorzata, Urban Roman 2012: Ocena wplywu produktywności i efektywności na pozycje konkurencyjnq przemystu spożywczego, [w] Monitoring i ocena konkurencyjności polskich producentów żywności (2), Iwona Szczepaniak (red.), IERiGŻ-PIB, Warszawa, s. $134-150$.

Koszarek Marita 2005: Przetwórstwo ryb, [w] Wstępna analiza trzech potencjalnych klastrów w województwie zachodniopomorskim, Stanisław Szultka (red.), Instytut Badań nad Gospodarką Rynkową, Gdańsk, s. 4-26.

Kubala Sebastian, Firlej Chrystian 2018: Researching the Competitiveness of the Fishing Industry in the Region of the Baltic Countries, „Zagadnienia Ekonomiki Rolnej”, nr 2 (355), s. 91-106 . 
Latruffe Laure 2010: Competitiveness, Productivity and Efficiency in the Agricultural and AgriFood sectors, „OECD Food, Agriculture and Fisheries Papers”, no. 30.

Morska Gospodarka Rybna w 2005 r. 2006, MIR-PIB, Gdynia.

Morska Gospodarka Rybna w 2006 r. 2007, MIR-PIB, Gdynia.

Morska Gospodarka Rybna w 2007 r. 2008, MIR-PIB, Gdynia.

Morska Gospodarka Rybna w 2008 r. 2009, MIR-PIB, Gdynia.

Morska Gospodarka Rybna w latach 20015-2016 2017, MIR-PIB, Gdynia.

Mroczek Robert, Tereszczuk Mirosława 2013: Wydajność pracy jako jeden zelementów decydujacych o międzynarodowej konkurencyjności polskiego przemystu spożywczego, „Problemy Rolnictwa Światowego”, nr 13(28)-2, s. 51-58.

Nadiri M. Ishaq, Nandi Banani 1999: Technical Change, Markup, Divestiture and Productivity Growth in the U.S. Telecommunications Industry, „The Review of Economics and Statistics", Harvard University, vol. 81(3), s. 488-498.

Rynek ryb - stan i perspektywy. Analizy rynkowe 2017, IERiGŻ-PIB, Warszawa.

Szczepaniak Iwona 2012: Wskaźnikowa ocena międzynarodowej konkurencyjności przemystu spożywczego, [w] Monitoring i ocena konkurencyjności polskich producentów żywności (2), Iwona Szczepaniak (red.), IERiGŻ-PIB, Warszawa, s. 38-50.

\section{Sebastian Kubala}

\section{THE PRODUCTIVE FACTORS IN THE FISH PROCESSING INDUSTRY IN POLAND DURING THE POST-ACCESSION PERIOD}

\section{Summary}

The study of the level and dynamics of changes of productivity of individual sectors allows to evaluate possible effectiveness of the resources used as well as identification of sources of production growth. It shows the extent to which changes in the level of the industry is dependent on factors of work and capital. The aim of the work was to study the efficiency of production factors in the fish processing industry in Poland in the years 2005-2016. To determine the rate of changes of the efficiency of the production factors there were indicators used that were based on production, employment and gross value of fixed assets. The study showed that in the fish processing industry there was a general growth tendency of labor productivity. There were also observed adverse changes in capital productivity. The greater impact on the level of production has a capital factor than the level of employment. In addition, the value of production increased at a rate faster than the total expenditure of factors shaping it.

Adres do korespondencji: Mgr Sebastian Kubala (orcid.org/0000-0003-4021-9173) Uniwersytet Ekonomiczny w Krakowie Katedra Rozwoju Organizacji ul. Rakowicka 27, 31-510 Kraków e-mail: kubalas@uek.krakow.pl 